\title{
PERPUSTAKAAN ANAK KOTA PONTIANAK
}

\author{
Deveny Starling', Yudi Purnomo², Irwin $^{3}$ \\ ${ }^{1}$ Mahasiswa, Program Studi Arsitektur, Fakultas Teknik, Universitas Tanjungpura. \\ d.starling2498@gmail.com \\ ${ }^{2}$ Program Studi Arsitektur, Fakultas Teknik, Universitas Tanjungpura \\ ${ }^{3}$ Program Studi Arsitektur, Fakultas Teknik, Universitas Tanjungpura
}

Naskah diajukan pada: 20 September 2020

Naskah revisi akhir diterima pada: 23 September 2020

\begin{abstract}
Abstrak
Persoalan rendahnya budaya literasi dan minat baca di Kota Pontianak dapat ditanggulangi dengan mendekatkan budaya literasi dan minat baca sejak dini pada anak-anak. Penyediaan fasilitas berupa perpustakaan khusus anak yang dapat mewadahi kegiatan membaca dan belajar anak sesuai dengan karakter dan kebutuhannya dibutuhkan untuk meningkatkan budaya literasi dan minat baca anak namun hingga saat ini perpustakaan khusus anak belum tersedia di Kota Pontianak. Perpustakaan anak adalah perpustakaan yang dikhususkan untuk mewadahi kegiatan belajar anak yang disesuaikan untuk memenuhi kebutuhan anak secara khusus. Adapun kegiatan yang ada di perpustakaan anak adalah kegiatan belajar dan bermain secara edukatif serta penyediaan layanan anak sebagai kegiatan pendukung. Lokasi perancangan Perpustakaan Anak Kota Pontianak berada pada Jalan Ahmad Yani. Konsep dalam perancangan berupa permainan warna dan bentuk pada facade bangunan, penyediaan lingkungan alami berupa taman dan inner courtyard serta konsep tatanan ruang dalam dengan sistem open plan. Proses perancangan ini bertujuan menghasilkan perpustakaan anak yang mengekspresikan suasana kondusif, imajinatif dan rekreatif yang sesuai dengan karakteristik anak.
\end{abstract}

Kata-kata Kunci: Perpustakaan Anak, Literasi, Kota Pontianak

\begin{abstract}
The issue of low literacy culture and reading interest in Pontianak City can be overcome by introducing children a culture of literacy and reading interest from an early age. Provision of special library facilities for children that can accommodate children's reading and learning activities in accordance with their characters and needs is needed to improve literacy culture and reading needs of children. However, until now children's library has not been available in Pontianak. Children's library is a library that is devoted to accommodating children's learning activities that are adjusted again to meet the special needs of children The activities in the children's library are educative learning and play activities and the provision of children's services as supporting activities. The design of the Pontianak City Children's Library is located on Ahmad Yani street. The design concepts are processed with colors and shapes on the building facade, the provision of a natural environment in the form of a garden and inner courtyard as well as the concept of indoor layout using an open plan system. This design process aims to create a children's library that expresses a conducive, imaginative and creative atmosphere that is appropriate to the characteristics of the child.
\end{abstract}

Keywords: Children's Library, Literacy, Pontianak City

\section{Pendahuluan}

Kualitas SDM (Sumber Daya Manusia) di Indonesia saat ini masih tergolong rendah hal ini berdasarkan pada Human Development Reports (2019) menyatakan Human Development Index (HDI) /Indeks Pembangunan Manusia (IPM) Indonesia berada pada tingkat 116 dari 188 negara dengan index 0.694. Peningkatan Sumber Daya Manusia (SDM) dapat dilakukan dengan berbagai cara salah satunya dengan meningkatkan minat membaca dan budaya literasi. 
Faktanya budaya membaca dan literasi Indonesia pada saat ini masih tergolong rendah, hal ini berdasarkan pada Central Connecticut State University (2016), dimana negara Indonesia menduduki peringkat 60 dari 61 negara. Selain itu, menurut Solihin (2019), indeks aktivitas literasi membaca 34 provinsi di Indonesia, tidak ada satu pun provinsi yang masuk dalam kategori aktivitas literasi tinggi serta tiga provinsi terendah berada di Papua, Papua Barat dan Kalimantan Barat.

Rendahnya minat baca dan literasi terjadi juga di Kota Pontianak yang merupakan Ibu Kota Kalimantan Barat. Berbagai upaya Pemerintah Kota Pontianak untuk mengatasi masalah ini terlihat dari penyediaan beberapa fasilitas membaca di area publik. Menurut Dinas Perpustakaan dan Kearsipan Kota Pontianak (2019), jumlah pengunjung kategori Taman Kanak-Kanak (TK) \& Sekolah Dasar (SD) di beberapa rumah baca dan perpustakaan di Pontianak cukup tinggi. Data tersebut memperlihatkan bahwa anak-anak di Kota Pontianak berminat pada kegiatan membaca.

Kota Pontianak, menurut Dinas Kependudukan dan Pencatatan Sipil (2019) dengan jumlah anak sebanyak 163.756 jiwa, saat ini masih belum memiliki perpustakaan khusus anak yang memperhatikan kebutuhan dan perilaku anak. Perancangan perpustakaan anak mempertimbangkan banyak hal terkait anak sebagai pengguna utama. Anak memiliki karakteristik, kebutuhan hingga proses belajar yang berbeda dengan orang dewasa. Salah satu karakter anak yang menonjol adalah senang berimajinasi dan gemar bermain. Kemampuan berimajinasi merupakan hal yang krusial bagi perkembangan anak, yang memiliki dampak kepada kemampuan belajar serta bagaimana anak berpikir kritis dan memecahkan masalah secara kreatif. Sedangkan dalam proses belajar anak cenderung bersifat mendasar dan tidak sekompleks orang dewasa. Proses belajar anak disebut dengan istilah "Play Based Learning". Play Based Learning adalah istilah yang digunakan dalam edukasi dan psikologi anak untuk mendeskripsikan bagaimana anak dapat belajar terhadap dunia di sekitarnya. Berdasarkan penjelasan di atas maka dibutuhkan fasilitas Perpustakaan Anak di Kota Pontianak yang di dalamnya menyediakan lingkungan dengan suasana kondusif, imajinatif dan rekreatif sesuai dengan karakteristik anak.

\section{Kajian Pustaka}

Menurut Sulistyo (1994), perpustakaan anak adalah perpustakaan yang ditujukan untuk anak sehingga koleksi, tata ruang dan desain perpustakaan disesuaikan lagi dengan standar, kebutuhan dan kenyamanan anak. Sedangkan menurut Mursid (2015), usia anak merupakan periode awal yang paling penting dan mendasar sepanjang rentang pertumbuhan dan perkembangan manusia. Tahapan anak dapat dibedakan kedalam tahap sebelum sekolah atau masa pertumbuhan (usia 1-2 tahun), prasekolah dan masa taman kanak-kanak (usia 3-5 tahun), usia awal sekolah (umur 6-7 tahun), elementer tengah (usia 8-9 tahun) dan elementer akhir (usia 10-12 tahun).

Menurut Persia (2013), desain perpustakaan anak berbeda dengan desain perpustakaan pada umumnya. Perpustakaan anak memerlukan tata ruang semenarik mungkin dengan pemberian warna, gambar dan ornamen yang sesuai dengan anak. Perpustakaan diharapkan menjadi tempat yang menyenangkan bagi anak yang tidak hanya sebagai tempat belajar tetapi juga menjadi tempat bermain dan tempat anak menumbuhkan kecakapan sosialnya.

Pengertian kondusif menurut Kamus Besar Bahasa Indonesia (2019) adalah kondisi tenang atau diartikan sebagai suatu kondisi yang mendukung untuk terjadinya suatu aktivitas atau tujuan tertentu. Menurut Veramyta (2012), penciptaan lingkungan dengan suasana kondusif pada perpustakaan anak dapat diwujudkan melalui penyediaan alat belajar yang sesuai dengan kebutuhan anak, penyediaan berbagai jenis layanan anak, penyediaan ruang yang cukup luas untuk anak beraktivitas, pemilihan perabot dan desain ruang yang sesuai dengan karakter anak, penciptaan ruang publik yang dapat membantu anak berinteraksi dengan sesamanya, penyediaan papan penanda (signage) pada area tertentu dilengkapi dengan gambar atau piktogram, penghawaan pada ruangan yang disesuaikan dengan kenyamanan anak dan pertimbangan akustika dengan pemilihan material yang dapat mereduksi kebisingan. 
Imajinasi menurut Kamus Besar Bahasa Indonesia (2019) adalah daya pikir untuk membayangkan (dalam angan-angan) atau menciptakan gambar (lukisan, karangan dan sebagainya) kejadian berdasarkan kenyataan atau pengalaman seseorang. Menurut Veramyta (2012), penciptaan lingkungan dengan suasana imajinatif pada perpustakaan anak dapat diwujudkan melalui pengadaan berbagai bentuk dan warna pada ruang, permainan edukatif, penyediaan berbagai kegiatan yang dapat mendukung anak untuk berimajinasi berupa kegiatan bermain peran, mendongeng, menonton dan lainnya serta desain pada ruangan yang berangkat dari suatu tema tertentu yang akan memancing fantasi anak.

Rekreatif adalah suatu kegiatan yang bersifat rekreasi. Rekreasi menurut Kamus Besar Bahasa Indonesia (2019) adalah penyegaran kembali badan dan pikiran atau sesuatu yang menggembirakan hati dan menyegarkan seperti hiburan. Sehingga lingkungan rekreatif diartikan sebagai lingkungan yang menyediakan suasana yang menyenangkan dan menghibur. Penciptaan suasana rekreasi pada perpustakaan anak dapat diterapkan melalui beberapa cara yaitu dekorasi pada ruang perpustakaan, penyediaan berbagai media hiburan dan penyediaan layanan bimbingan.

\section{Metode}

Metode perancangan adalah suatu alat yang digunakan untuk menghasilkan sesuatu melalui tahapan-tahapan yang sistematis. Tahapan awal untuk merancang perpustakaan anak adalah pengenalan terlebih dahulu mengenai anak dan perpustakaan anak sehingga metode perancangan dari Snyder dan Catanese sesuai digunakan pada perancangan ini karena metode ini dimulai dari tahapan permulaan yang terdiri dari proses pengenalan dan pembatasan masalah yang akan dipecahkan. Kemudian dilanjutkan dengan proses persiapan, pengajuan usul, evaluasi dan tindakan/perancangan.

\section{Permulaan}

Tahap permulaan meliputi proses pengenalan dan pembatasan masalah yang akan dipecahkan. Proses pengenalan diawali dengan tinjauan mengenai anak dan perpustakaan anak. Kemudian melalui tinjauan tersebut dirumuskan pembatasan masalah.Tinjauan mengenai anak berfokus pada batasan tentang anak, karakter anak, metode belajar anak, pertumbuhan dan perkembangan anak serta faktor yang mempengaruhi. Sedangkan tinjauan mengenai perpustakaan anak berfokus pada sudi kasus bangunan sejenis dan literatur mengenai perpustakaan anak. Kemudian berdasarkan tinjauan terkait anak dan perpustakaan anak menghasilkan batasan masalah berupa perancangan perpustakaan anak sebagai sarana edukasi yang mengekspresikan suasana kondusif, imajinatif dan rekreatif dengan pendekatan karakteristik anak selaku pengguna utama.

\section{Persiapan}

Tahap persiapan terdiri dari dua kegiatan yakni kegiatan utama dan kegiatan penunjang. Kegiatan utama meliputi pengumpulan dan analisis informasi sedangkan kegiatan penunjang terdiri atas pengumpulan informasi terkait tapak/ lokasi perancangan perpustakaan anak. Tahap pengumpulan informasi terkait anak, perpustakaan anak dan lokasi perancangan diperoleh melalui studi literatur, studi preseden dan studi lapangan. Sedangkan tahap analisis menggunakan teknik analisis data penelitian kualitatif model Miles dan Huberman yang terdiri dari proses reduksi data, penyajian data dan terakhir penarikan kesimpulan.

\section{Pengajuan Usul}

Tahap selanjutnya setelah dilakukan tahap analisis adalah tahap sintesis. Tahap ini adalah tahap penarikan kesimpulan dari analisis yang telah dilakukan sebelumnya berupa usulan proses perancangan atau konsep perancangan perpustakaan anak.

\section{Evaluasi}

Tahap evaluasi menjadi pijakan untuk melakukan proses selanjutnya. Tahap evaluasi 
berlangsung proses evaluasi terhadap usulan proses perancangan atau konsep perancangan perpustakaan anak.

\section{Tindakan}

Tahap tindakan merupakan langkah untuk memulai pengaplikasian hasil rancangan perpustakaan anak. Proses ini juga disebut sebagai proses produksi produk berupa gambar kerja perpustakaan anak, spesifikasi teknis dan sebagainya.

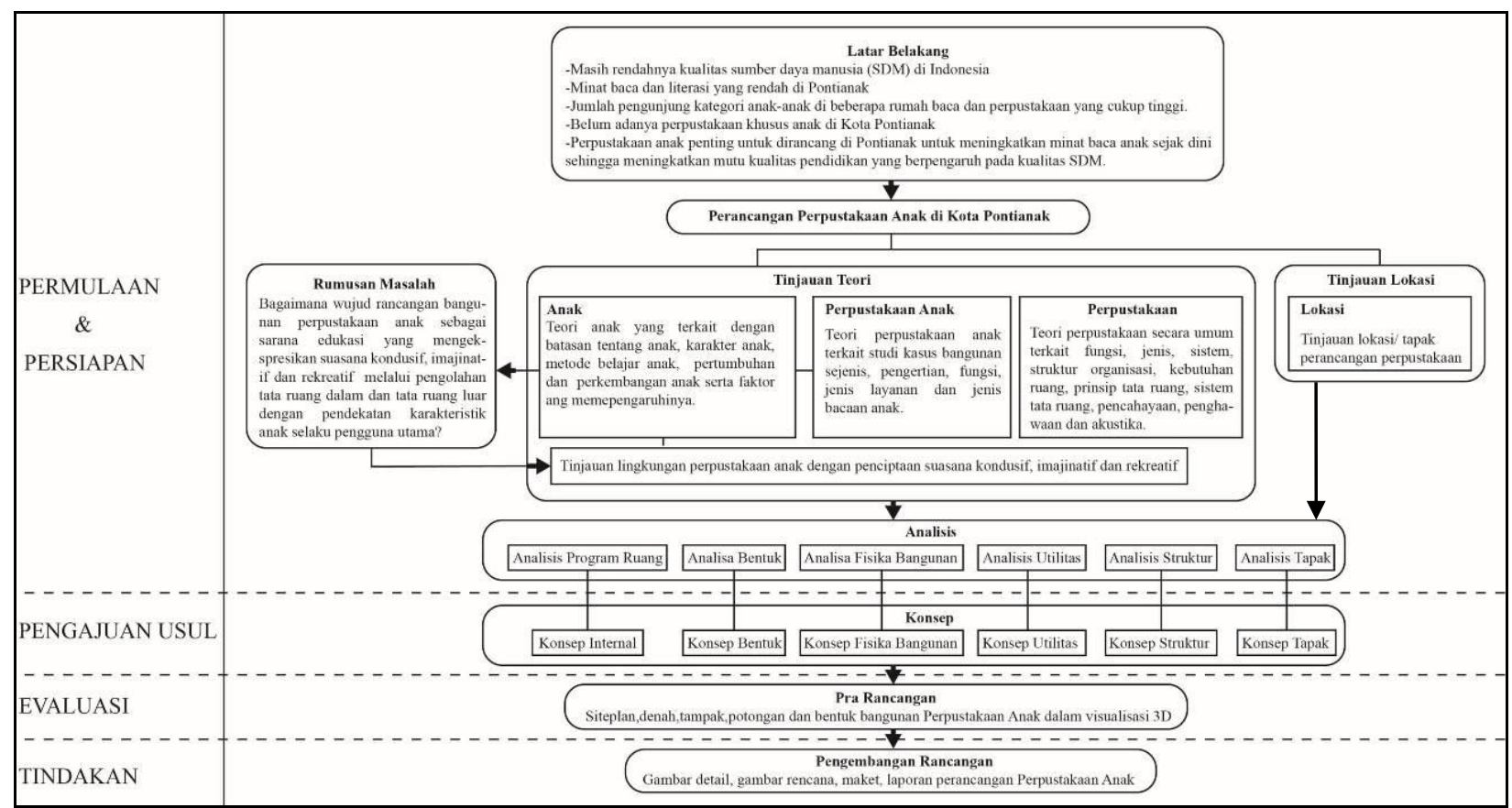

Gambar 1. Alur Perancangan Perpustakaan Anak Kota Pontianak

Sumber: Penulis, 2020

\section{Hasil dan Pembahasan}

Proses pembahasan meliputi proses pemilihan lokasi perancangan bangunan Perpustakaan Anak Kota Pontianak dan proses landasan konseptual hingga didapatkan hasil perancangan.

\section{Lokasi Perancangan}

Menurut Perpustakaan Nasional RI (2011), pemilihan lokasi perpustakaan Kabupaten/ Kota harus mempertimbangkan beberapa aspek yaitu berada pada lokasi yang mudah dilihat, dikenal, dan di jangkau masyarakat, dibawah kepemilikan atau kekuasaan pihak pemerintah daerah, memiliki status hukum yang jelas, jauh dari lokasi rawan bencana. Selain itu menurut Dirjen Pendidikan Tinggi RI (2004), lokasi perpustakaan harus memperhitungkan kenyamanan pemakai, perluasan jangka panjang, ketersediaan tanah dan dana. Serta yang terpenting lokasi perpustakaan anak sebaiknya berada di kawasan yang strategis dan mudah dijangkau oleh masyarakat sekitar khususnya anak-anak, misalkan pada kawasan yang terdapat playgroup, TK dan SD.

Lokasi perancangan berada di Jalan Ahmad Yani, Kelurahan Bansir Laut, Kecamatan Pontianak Tenggara, Kota Pontianak, Kalimantan Barat. Lokasi berada dekat dengan permukiman warga di sisi barat laut, utara, timur laut (kiri \& belakang) site. Di sisi barat dan barat daya (depan) site berhadapan dengan Jalan Ahmad Yani dan di sisi timur (kanan) site terdapat auditorium Universitas Tanjungpura. Lokasi perancangan dapat dilihat di Gambar 2.

Berdasarkan peraturan Rencana Tata Ruang Wilayah Kota Pontianak Tahun 2013-2033 Koefisien Dasar Bangunan (KDB) lokasi sebesar maksimal 70\%, Koefisien Lantai Bangunan (KLB) 
sebesar maksimal 2,1 dan Koefisien Dasar Hijau sebesar minimal 40\%. Luas site adalah \pm 1,1 hektar. Lokasi perancangan memiliki infrastruktur berupa jalan, jaringan listrik dan penyediaan air bersih.

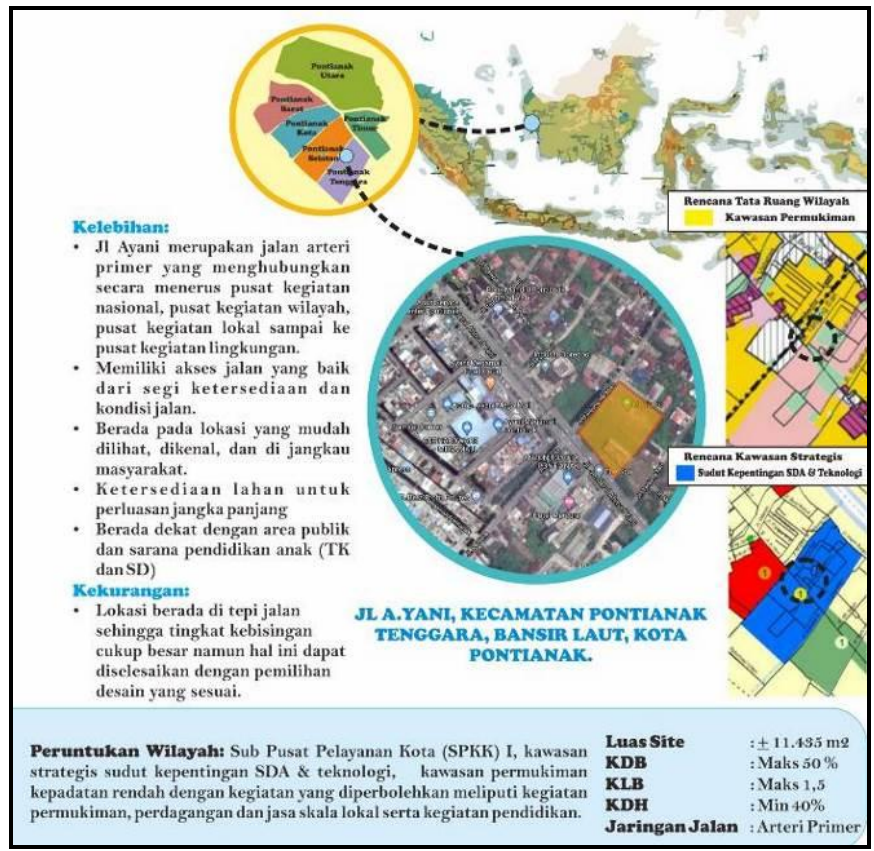

Gambar 2. Lokasi Perancangan Perpustakaan Anak Kota Pontianak

Sumber: Penulis, 2020

\section{Landasan Konseptual}

Landasan konseptual merupakan proses analisis untuk mencapai tujuan perancangan. Landasan konseptual merupakan proses analisis untuk mencapai tujuan perancangan. Proses analisis perancangan Perpustakaan Anak Kota Pontianak terbagi menjadi analisis fungsi, pelaku, eksternal, gubahan bentuk, struktur dan utilitas. Fungsi pada bangunan perpustakaan anak terbagi menjadi dua yaitu fungsi utama dan fungsi penunjang. Fungsi utama yaitu sebagai fungsi pendidikan dan fungsi penunjang meliputi fungsi informatif, budaya, rekreatif dan simpan karya. Penjelasan fungsi dapat dilihat di Gambar 3.

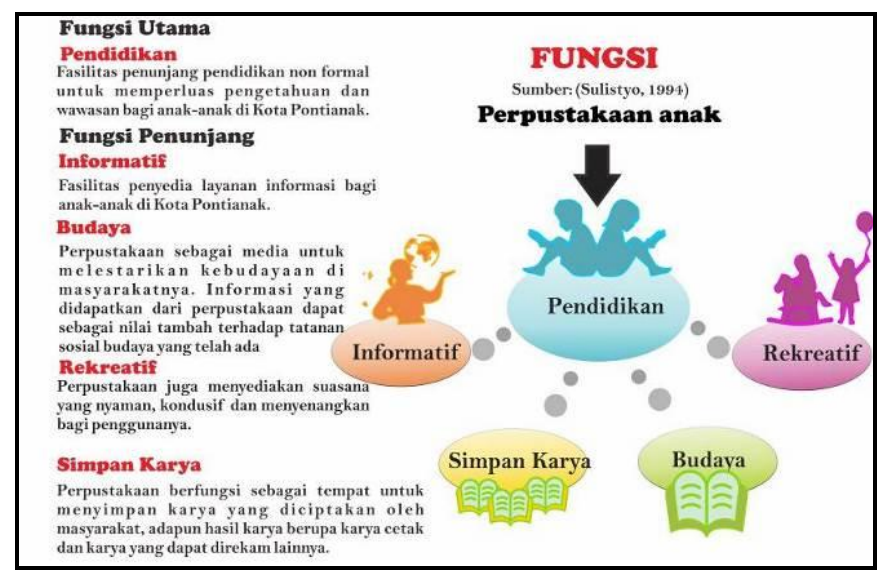

Gambar 3. Fungsi Perpustakaan Anak Kota Pontianak Sumber: Penulis, 2020

Analisis organisasi ruang menjelaskan pada hubungan antar ruang. Hubungan antar ruang di nilai berdasarkan pada fungsi dan pemanfaatan ruang. Ruang dalam bangunan Perpustakaan Anak 
Kota Pontianak terbagi menjadi kelompok ruang utama dan ruang penunjang. Ruang utama ditunjukkan dengan ruang lobi, ruang sirkulasi, ruang koleksi, ruang baca dan lainnya. Sedangkan ruang penunjang untuk pemanfaatan kegiatan pengelolaan terkait administrasi terdiri dari ruang pengelola, ruang bedah buku, ruang mekanikal dan elektrikal, toilet dan lainnya. Analisis organisasi ruang dapat dilihat di Gambar 4.

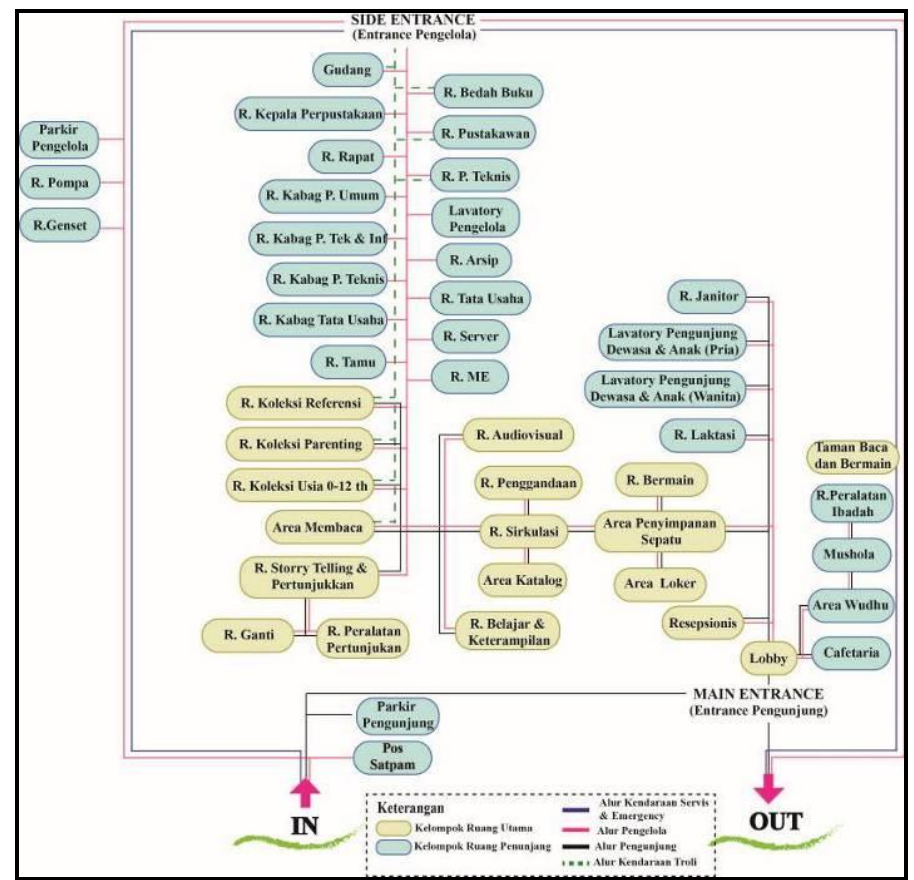

Gambar 4. Analisis Organisasi Ruang Perpustakaan Anak Kota Pontianak Sumber: Penulis, 2020

Peletakan bangunan Perpustakaan Anak Kota Pontianak diletakkan di tengah site, mundur dari Jalan Ahmad Yani agar kebisingan dan polusi kendaraan dari Jalan Ahmad Yani dapat tereduksi. Posisi bangunan juga mengikuti aturan yang telah ditetapkan sehingga pada area sempadan bangunan akan digunakan sebagai area parkir dan ruang terbuka hijau. Analisis peletakan dapat dilihat di Gambar 5.

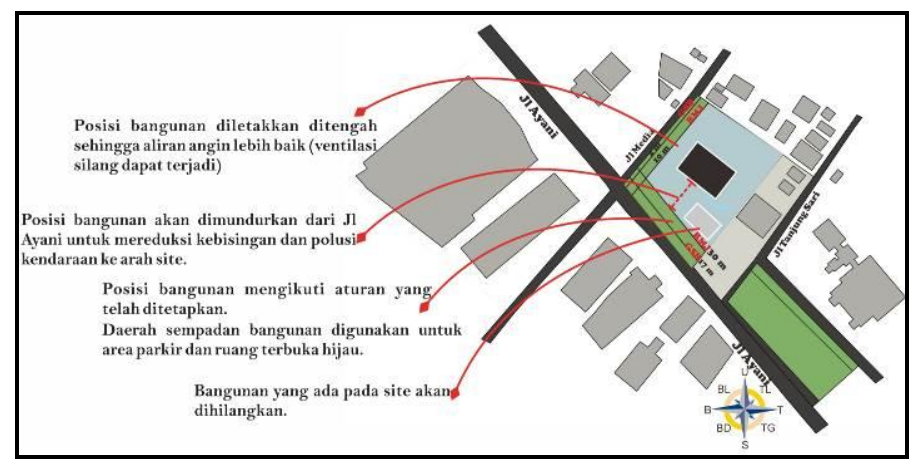

Gambar 5. Analisis Peletakan Perpustakaan Anak Kota Pontianak

Sumber: Penulis, 2020

Orientasi utama bangunan perpustakaan anak menghadap Jalan Ahmad Yani (barat daya) karena kondisi Jalan Ahmad Yani yang ramai dan akses dari jalan ke site yang mudah sehingga hal ini akan memudahkan visual dan akses pengunjung ke bangunan. Orientasi ini juga menyesuaikan orientasi bangunan di sekitar site. Sedangkan orientasi pendukung bangunan menghadap ke arah 
timur laut sehingga visual bangunan juga dapat terlihat dari Jalan Media. Analisis orientasi dapat dilihat di Gambar 6.

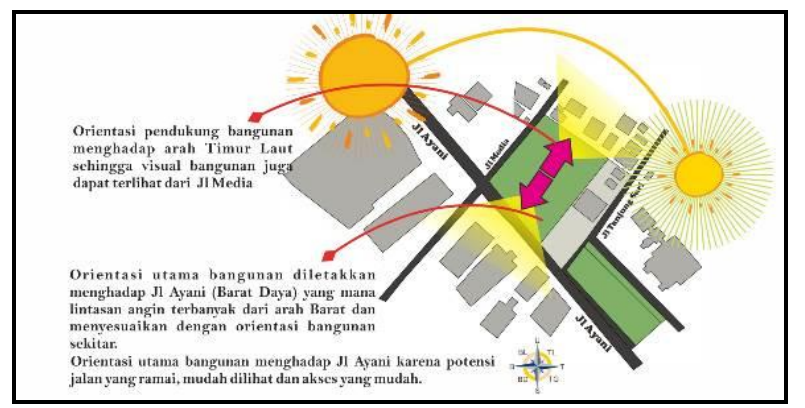

Gambar 6: Analisis Orientasi Perpustakaan Anak Kota Pontianak

Sumber: Penulis, 2020

Sirkulasi disite perpustakaan anak dipisah menjadi dua yaitu sirkulasi pengunjung dan sirkulasi pengelola. Sirkulasi pengunjung diletakkan pada area depan site, dekat dengan akses masuk utama sedangkan sirkulasi pengelola diletakkan pada area belakang site. Akses masuk dan keluar dibuat terpisah, yang mana akses masuk berasal dari Jalan Ahmad Yani dan akses keluar dari Jalan Media. Pemisahan akses ini dimaksudkan untuk kelancaran sirkulasi pada site dan juga karena kondisi kedua jalan yang memungkinkan untuk diakses. Analisis sirkulasi dapat dilihat di Gambar 7.

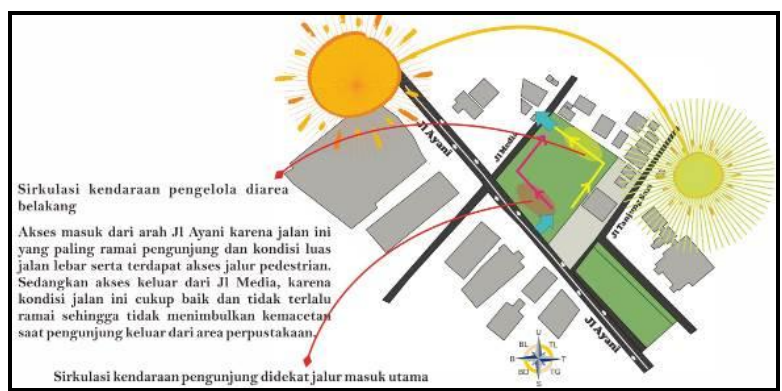

Gambar 7: Analisis Sirkulasi Perpustakaan Anak Kota Pontianak Sumber: Penulis, 2020

Zonasi untuk area publik diletakkan di area depan site dekat dengan akses utama hal ini agar memudahkan akses pengunjung serta memudahkan visual ke dalam dan keluar site. Kemudian untuk area semi publik, semi privat dan privat diletakkan dekat dengan zona publik untuk memudahkan akses pencapaian dan karena adanya keterikatan pada hubungan ruang antara ketiga zona tersebut. Sedangkan pada area servis diletakkan di area barat laut dan timur laut karena dekat dengan akses selokan dan parit serta zona servis merupakan area yang jarang digunakan sehingga cocok diletakkan pada area barat yang terkena matahari sore. Analisis zonasi dapat dilihat di Gambar 8.

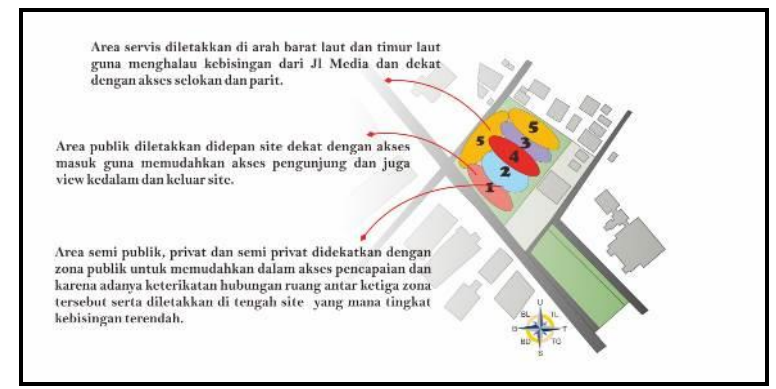

Gambar 8: Analisis Zonasi Perpustakaan Anak Kota Pontianak Sumber: Penulis, 2020 
Penggunaan vegetasi pada area site bertujuan sebagai penghalau kebisingan, pereduksi panas matahari serta sebagai elemen estetika bagi area perpustakaan anak. Peletakan vegetasi peneduh pada area barat daya untuk mereduksi kebisingan dan panas matahari. Kemudian area barat daya juga akan dibuat taman, agar panas matahari dari arah barat daya dapat direduksi serta taman juga berfungsi untuk menyejukkan sirkulasi udara di area site karena arah angin terbanyak datang dari arah barat. Sedangkan untuk area barat dan barat laut akan ditanami vegetasi sebagai penghalau panas matahari dan kebisingan. Area timur dan timur laut yang terkena matahari pagi akan ditanami vegetasi tetapi tidak terlalu banyak, hal ini bertujuan agar cahaya matahari pagi tetap masuk tetapi tidak secara langsung. Analisis vegetasi dapat dilihat di Gambar 9.

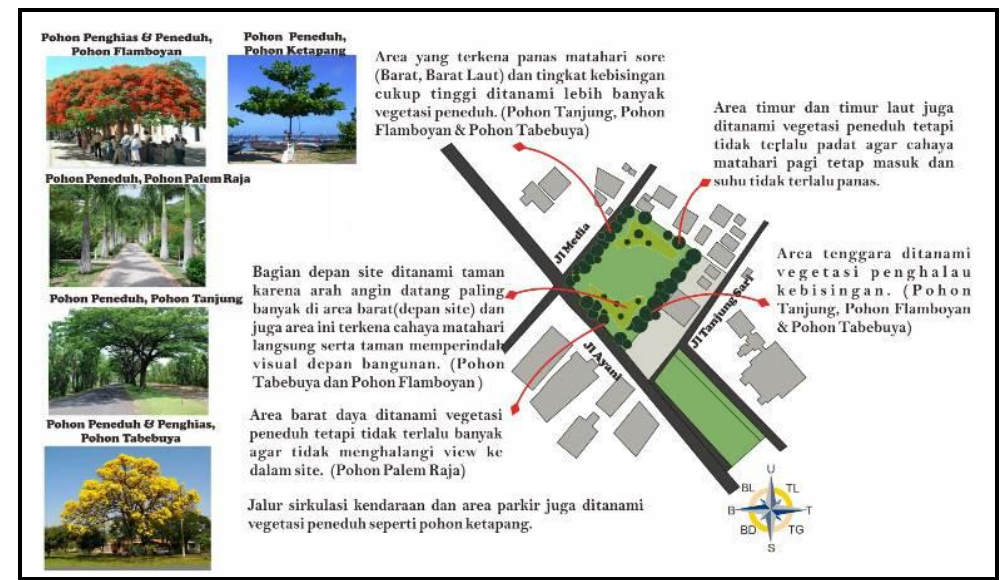

Gambar 9: Analisis Vegetasi Perpustakaan Anak Kota Pontianak

Sumber: Penulis, 2020

Analisis bentuk bangunan perpustakaan anak berlandaskan pada fungsi perpustakaan dan penekanan perilaku anak. Perpustakaan anak termasuk sebagai sarana pendidikan sehingga penekanan terhadap bentuk yang fungsional atau efektifitas bentuk terkait pada ruang-ruangnya merupakan hal yang utama sehingga dipilihlah bentuk dasar berupa persegi. Kemudian pertimbangan faktor karakter anak senang mengeksplorasi lingkungan sekitarnya sebagai bentuk pembelajaran maka penyediaan lingkungan alami sebagai pendukung lingkungan buatan perlu disediakan. Lingkungan alami dapat berupa tempat dimana anak dapat bermain, mengeksplorasi dan berinteraksi dengan alam sekitar. Sehingga bentuk dasar bangunan dibuat dengan perpaduan inner courtyard yang menjadi pusat kegiatan bagi anak untuk melakukan kegiatan bermain dan juga membaca.

Konsep gubahan bentuk Perpustakaan Anak Kota Pontianak menerapkan konsep rekreatif, imajinatif dan kondusif. Penerapan konsep melalui permainan warna dan bentuk fasad bangunan. Konsep diterapkan dengan susunan balok- balok yang tidak beraturan yang mana balok- balok tersebut menggunakan variasi warna yang berbeda untuk memberikan kesan menyenangkan (rekreatif) dan imajinatif. Balok-balok disusun dengan dua dimensi balok yang berbeda yaitu pada balok 1 dengan dimensi $2 \times 2 \times 1 \mathrm{~m}$ dan balok 2 dengan dimensi $2 \times 2 \times 0,5 \mathrm{~m}$, tujuannya untuk memunculkan visual permainan bentuk bagi orang yang melihat bangunan tersebut. Selain itu juga bertujuan sebagai insulasi dan shading panas matahari ke dalam bangunan, karena kondisi bagian depan site yang terkena matahari sore sehingga penerapan konsep ini juga dimaksudkan untuk menjaga kondusifitas kegiatan di dalam bangunan dengan mengurangi panas matahari ke dalam bangunan.

Konsep rekreatif, imajinatif dan kondusif juga diterapkan pada atap bangunan yang menggunakan atap perisai dengan permainan warna berupa warna merah, jingga, biru, hijau dan putih. Pemberian warna pada atap selain sebagai penyesuaian terhadap konsep massa bangunan dibawah nya, juga dimaksudkan sebagai thermal coating. Karena warna cerah seperti merah, jingga, 
hijau, biru dan putih dapat memantulkan cahaya matahari lebih besar. Analisis gubahan bentuk dapat dilihat di Gambar 10.

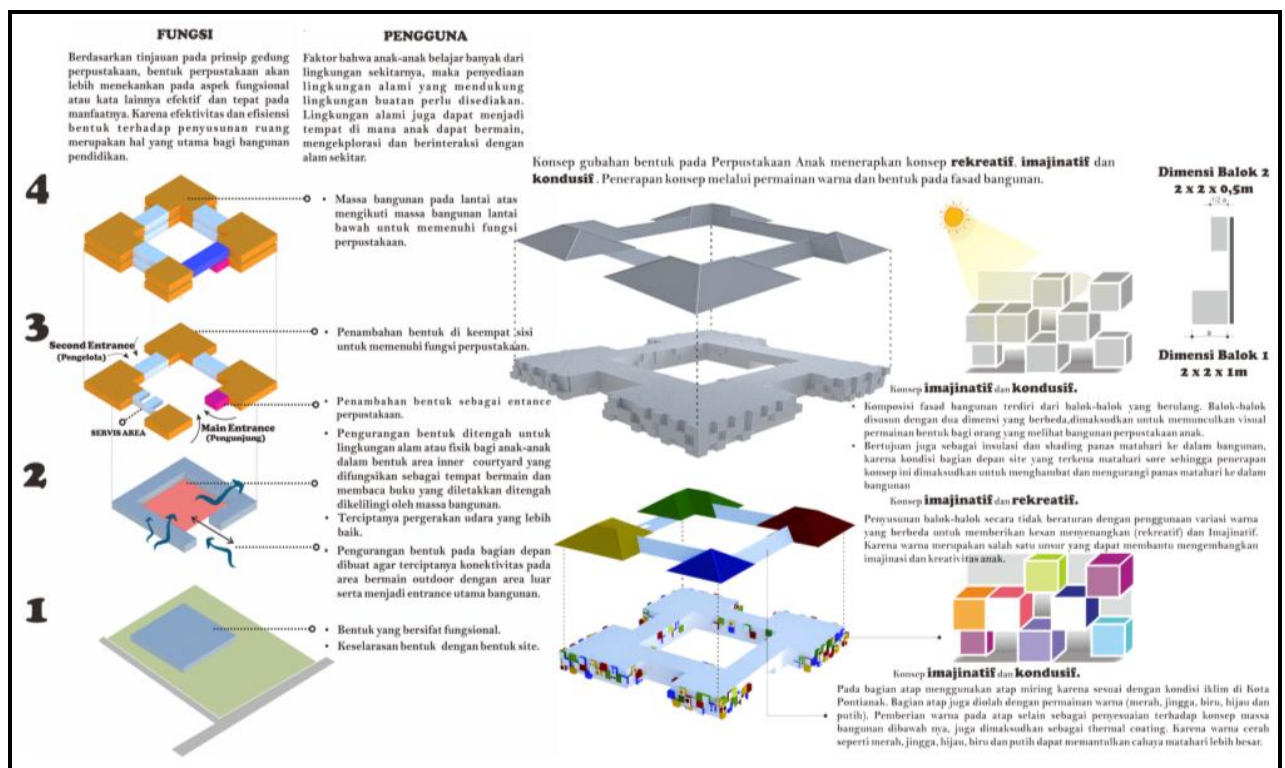

Gambar 10: Analisis Gubahan Bentuk Perpustakaan Anak Kota Pontianak Sumber: Penulis, 2020

Analisis konsep struktur terbagi menjadi dua jenis yaitu konsep struktur bawah dan atas. Struktur bawah meliputi struktur pondasi menggunakan pondasi tiang pancang beton bertulang dan struktur atas meliputi struktur rangka menggunakan struktur rangka beton bertulang, dinding menggunakan dinding bata ringan dan perpaduan dinding akustik, lantai menggunakan plat lantai beton dengan pelapis lantai vinyl dan keramik serta atap menggunakan struktur rangka baja dengan pelapis atap bitumen bergelombang. Analisis struktur dapat dilihat di Gambar 11.

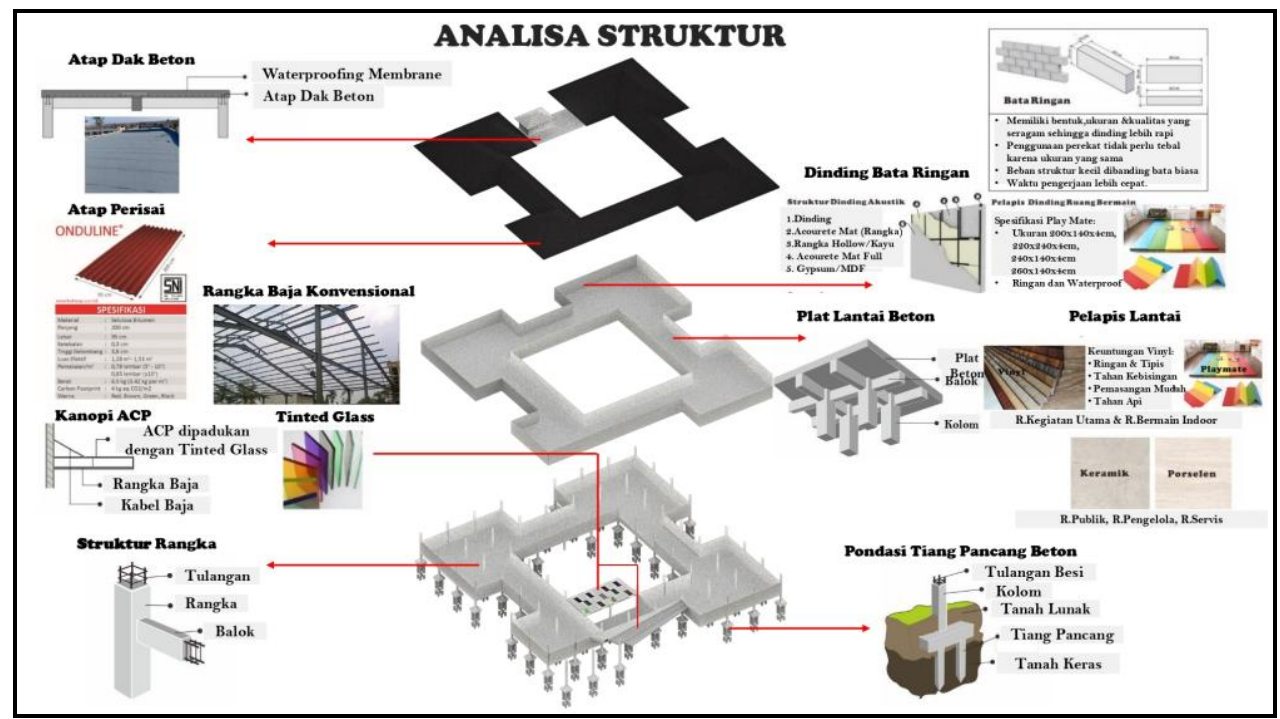

Gambar 11: Analisis Konsep Struktur Perpustakaan Anak Kota Pontianak Sumber: Penulis, 2020

Analisis utilitas terdiri sistem jaringan air bersih dan kotor, jaringan listrik, informasi dan komunikasi, sistem tata udara, sistem keamanan bangunan dan sistem transportasi bangunan. Jaringan air bersih menggunakan up feed system dengan cara air bersih yang bersumber dari 
Perusahaan Daerah Air Minum (PDAM) di tampung di groundwater tank kemudian di distribusikan menggunakan mesin pompa air menuju ruang-ruang yang membutuhkan. Sedangkan pengolahan air kotor menggunakan sistem pengolahan limbah pada umumnya. Air limbah dari wastafel dan floor drain akan dialirkan ke perangkap sabun dan air limbah dari kloset akan dialirkan ke septic tank sedangkan air limbah kafetaria dari wastafel akan dialirkan ke grease trap. Setelah itu, hasil pengolahan dari perangkap sabun, septic tank dan grease trap akan dialirkan ke Sewage Treatment Plant (STP) untuk diolah kembali sebelum air kotor di salurkan ke riol kota.

Jaringan listrik utama bersumber dari Perusahaan Listrik Negara (PLN) dan disediakan sumber listrik cadangan dengan generator set. Jaringan informasi dan komunikasi menggunakan jaringan internet, ceiling speaker dan microphone. Selain itu digunakan jaringan telepon yang bersumber dari Telkom yang kemudian disalurkan ke Private Automatic Branch Exchange (PABX) dan didistribusikan ke ruang-ruang yang membutuhkan.

Sistem tata udara menggunakan Air Conditioner (AC) sentral dengan Air Cooled System. Sistem keamanan bangunan terdiri dari penggunaan Closed Circuit Television (CCTV) dan sistem proteksi kebakaran. Sistem proteksi kebakaran pada bangunan Perpustakaan Anak menggunakan hidran halaman dan bangunan, PAR, detektor asap, sprinkler dan fire suppression system. Sistem transportasi bangunan pada perpustakaan anak mempertimbangkan faktor keamanan anak sehingga menggunakan ramp untuk area pengunjung dan tangga untuk area pengelola.

\section{Hasil Perancangan}

Perancangan bangunan Perpustakaan Anak Kota Pontianak menghasilkan gambar siteplan, denah, tampak, potongan, eksterior dan interior. Gambar siteplan bangunan Perpustakaan Anak Kota Pontianak menunjukkan akses masuk dari Jalan Ahmad Yani dan akses keluar dari Jalan Media. Tersedia area parkir pengunjung pada area depan dekat dengan akses masuk dan area samping bangunan serta area parkir pengelola berada di belakang bangunan. Tersedia tiga zona pedestrian, yang pertama berada di area selatan yang terhubung dengan jalur pedestrian Jalan Ahmad Yani, kedua berada di depan bangunan perpustakaan anak dan ketiga berada di barat laut yang diletakkan dekat dengan area parkir motor pengunjung. Zona pedestrian pada sisi depan bangunan dipadukan dengan taman sebagai salah satu bentuk lingkungan alamiah yang dihadirkan untuk memberikan pengalaman bagi anak bereksplorasi dengan lingkungan alami di sekitarnya. Gambar siteplan bangunan Perpustakaan Anak Kota Pontianak dapat dilihat di Gambar 12.

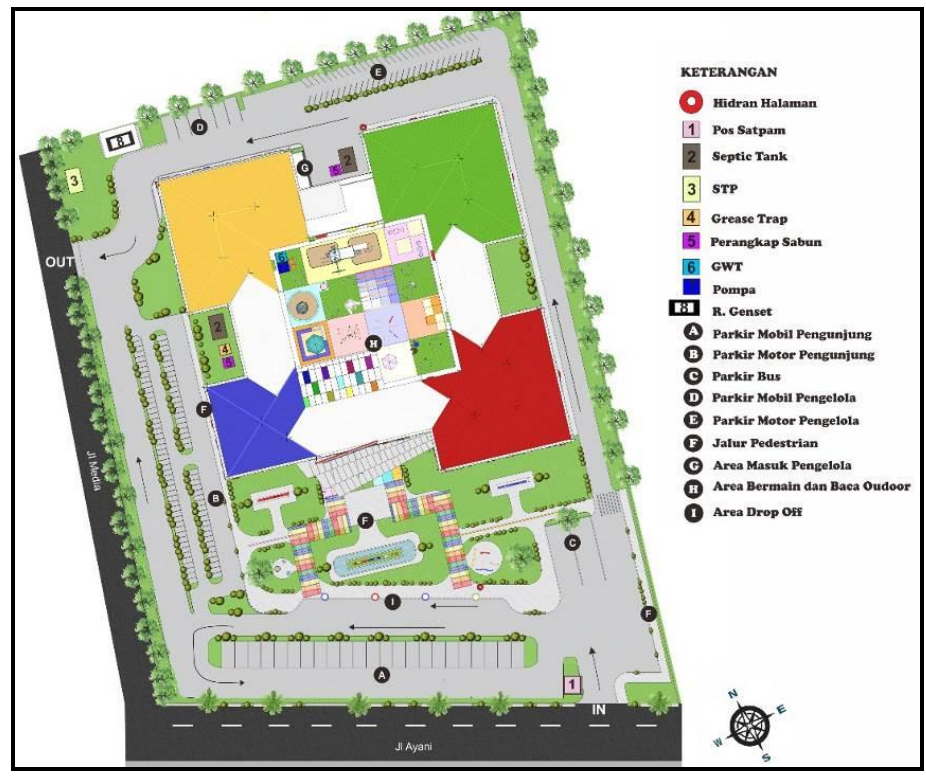

Gambar 12: Siteplan Bangunan Perpustakaan Anak Kota Pontianak

Sumber: Penulis, 2020 
Gambar denah perpustakaan anak menjelaskan hubungan antara ruang-ruang yang berada di dalam bangunan perpustakaan. Konsep penataan ruang perpustakaan anak menggunakan sistem tata ruang baur dan open plan sehingga meminimalkan penggunaan batas ruang seperti dinding antara satu ruang dengan ruang lainnya. Denah perpustakaan anak terbagi menjadi dua yaitu denah lantai dasar dan lantai satu. Pintu masuk utama bangunan perpustakaan anak ditunjukkan pada poin (A). Setelah memasuki pintu masuk terdapat area lobi dan resepsionis (poin B) yang berfungsi untuk kegiatan registrasi pengunjung perpustakaan. Sisi sebelah kanan lobi terdapat pintu masuk untuk area perpustakaan (poin C) dan ruang bermain indoor (poin D) sedangkan pada sisi sebelah kiri terdapat area kafetaria yang berfungsi sebagai area makan dan santai bagi pengunjung dan pengelola perpustakaan (poin E). Kemudian pada sisi bagian tengah terdapat area taman baca dan bermain yang dikelilingi oleh massa bangunan (poin F) yang berfungsi sebagai area untuk anak bermain permainan edukatif dan area anak membaca dengan santai. Area ini juga dilengkapi dengan area mushola dan toilet (poin G) yang terdapat pada sisi sebelah kiri bangunan. Selanjutnya di bagian belakang bangunan terdapat area pengelola perpustakaan anak (poin $\mathrm{H}$ ) dan area toilet (poin I) yang dapat diakses melalui area dalam perpustakaan. Gambar denah lantai dasar bangunan Perpustakaan Anak Kota Pontianak dapat dilihat di Gambar 13.

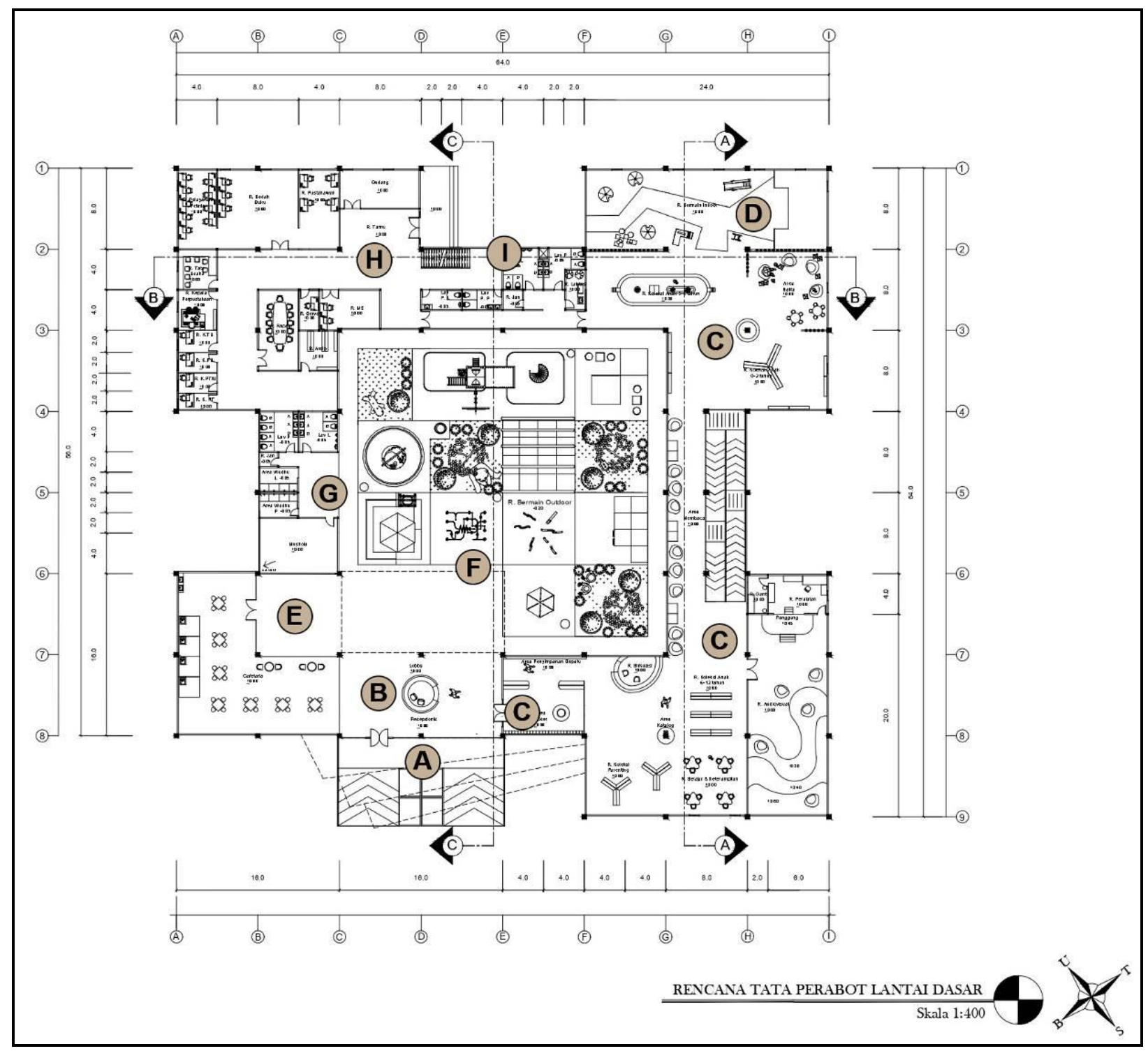

Gambar 13: Denah Lantai Dasar Bangunan Perpustakaan Anak Kota Pontianak Sumber: Penulis, 2020 
Gambar denah lantai dua menunjukkan susunan ruang dengan fungsi perpustakaan. Terdapat ramp (poin J) di sisi sebelah kanan bangunan yang terhubung dengan area perpustakaan lantai dasar. Setelah menaiki ramp, terdapat area koleksi anak 6-12 tahun, area katalog, area baca, ruang belajar dan keterampilan serta area sirkulasi (poin K) di sisi bagian depan bangunan. Selain itu terdapat ruang bermain indoor (poin L) di sisi kiri bangunan yang dapat diakses dari ruang koleksi anak 6-12 tahun dan ruang koleksi anak 0-5 tahun. Sedangkan di sisi kanan belakang bangunan terdapat area koleksi referensi, area balita dan area baca (poin M). Bagian sisi kiri belakang bangunan terdapat area koleksi anak 0-5 tahun, area koleksi parenting, area baca dan area sirkulasi (poin N). Bagian sisi belakang juga terdapat area pengelola (poin $\mathrm{O}$ ) yang terhubung dengan area pengelola lantai dasar serta area toilet (poin P) untuk melayani pengunjung pada lantai satu. Gambar denah lantai dasar bangunan Perpustakaan Anak Kota Pontianak dapat dilihat di Gambar 14.

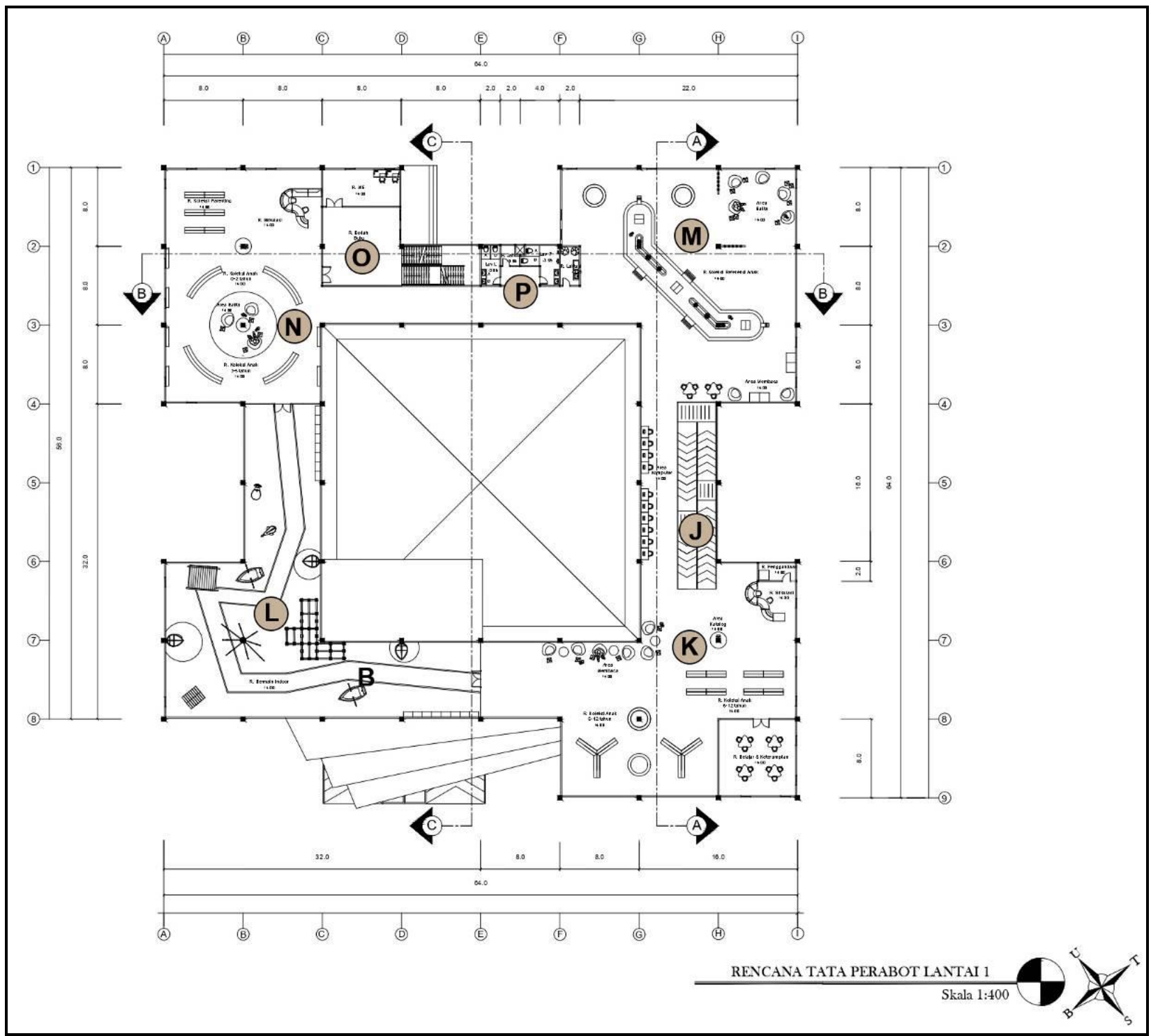

Gambar 14: Denah Lantai Satu Bangunan Perpustakaan Anak Kota Pontianak Sumber: Penulis, 2020

Gambar tampak bangunan Perpustakaan Anak Kota Pontianak menunjukkan tampilan/ facade bangunan dari segala sisi (depan, kanan, kiri dan belakang). Bangunan perpustakaan anak memiliki tampilan yang dibuat menyerupai dari satu sisi ke sisi lainnya agar visual dapat dilihat dari segala sisi. Gambar tampak bangunan Perpustakaan Anak Kota Pontianak dapat dilihat di Gambar 15. 


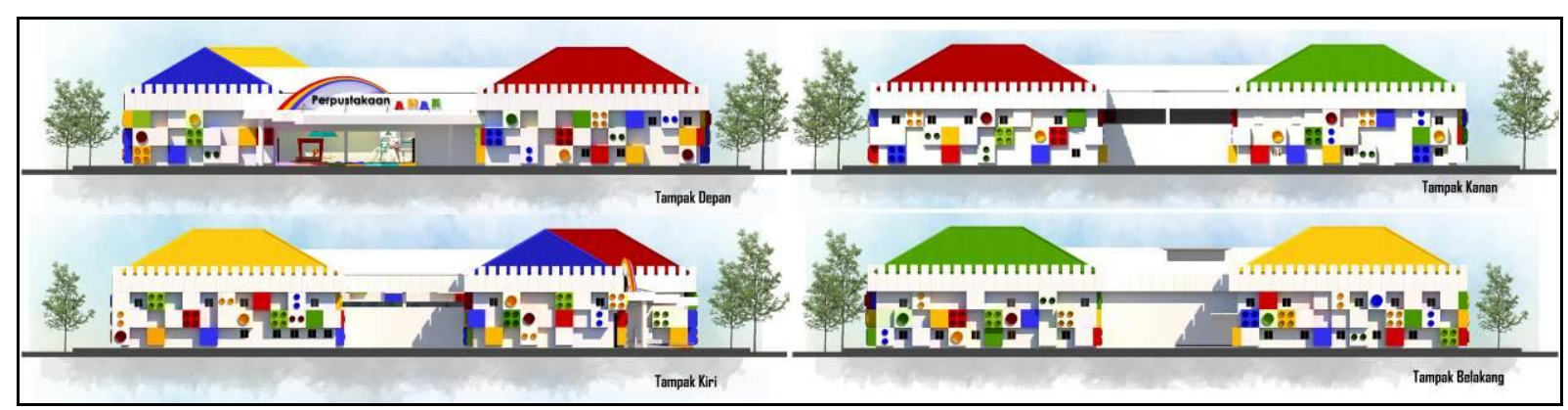

Gambar 15: Tampak Bangunan Perpustakaan Anak Kota Pontianak Sumber: Penulis, 2020

Gambar potongan bangunan Perpustakaan Anak Kota Pontianak menunjukkan detail bangunan dari potongan secara vertikal dan horizontal. Secara umum gambar potongan menunjukkan informasi mengenai dimensi dan spesifikasi teknis bangunan. Informasi tersebut meliputi ketinggian bangunan, jenis pondasi, jenis rangka atap dan lainnya. Rencana potongan bangunan Perpustakaan Anak Kota Pontianak dapat dilihat di Gambar 16.

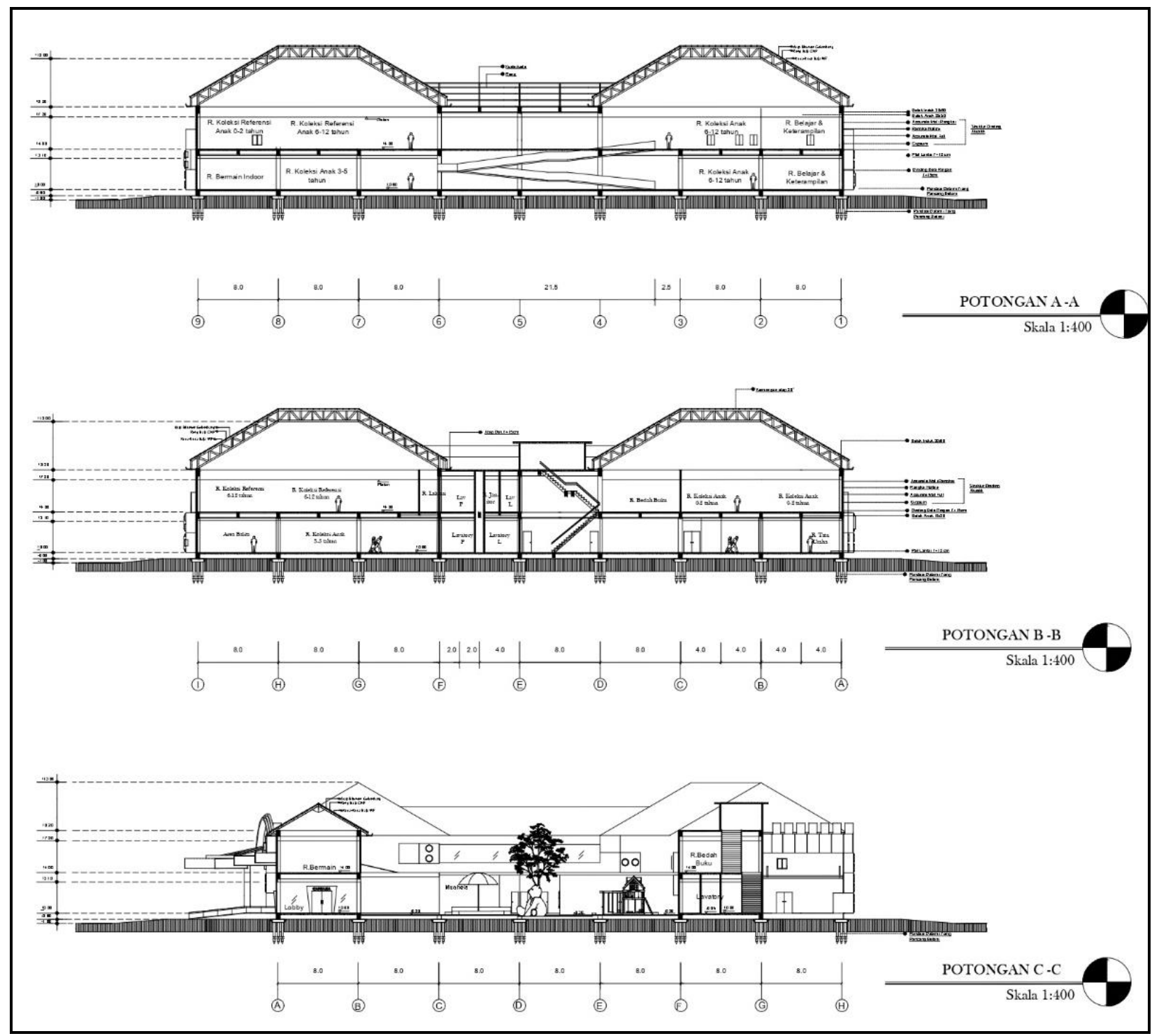

Gambar 16: Potongan Bangunan Perpustakaan Anak Kota Pontianak Sumber: Penulis, 2020 
Gambar suasana eksterior menunjukkan gambaran suasana bangunan dengan elemen disekitarnya yang meliputi area parkir, area pedestrian, taman dan area bermain. Sedangkan gambar suasana interior merupakan gambaran suasana penataan ruang dalam suatu bangunan. Gambar eksterior dan interior bangunan Perpustakaan Anak Kota Pontianak dapat dilihat di Gambar 17 dan 18.

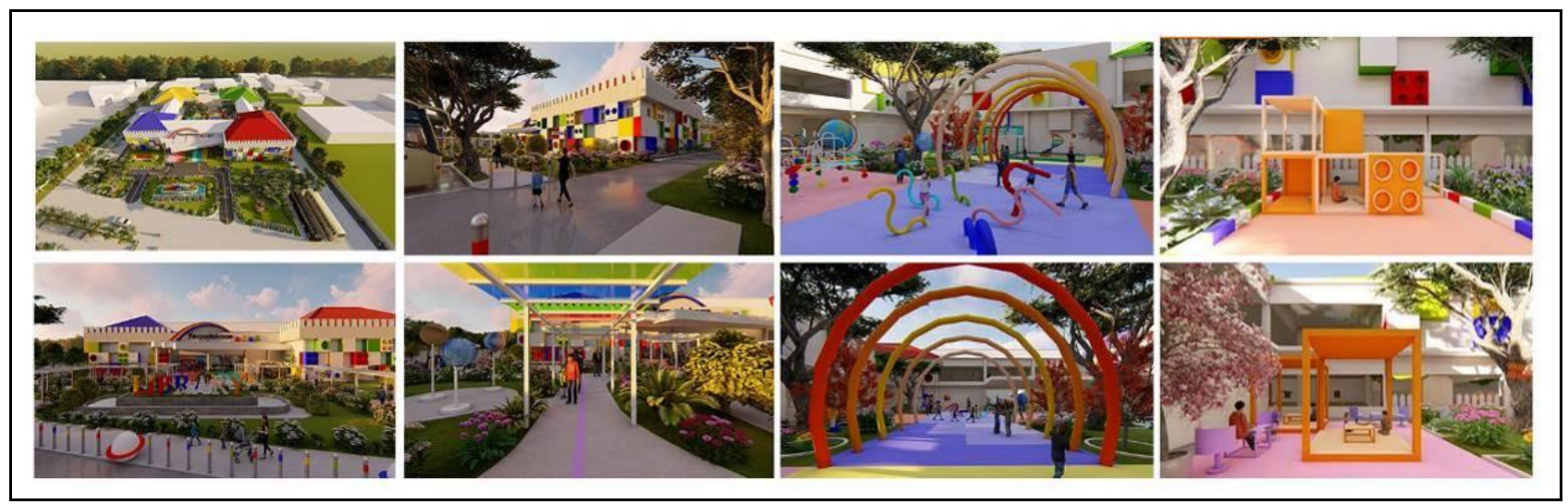

Gambar 17: Eksterior Bangunan Perpustakaan Anak Kota Pontianak Sumber: Penulis, 2020

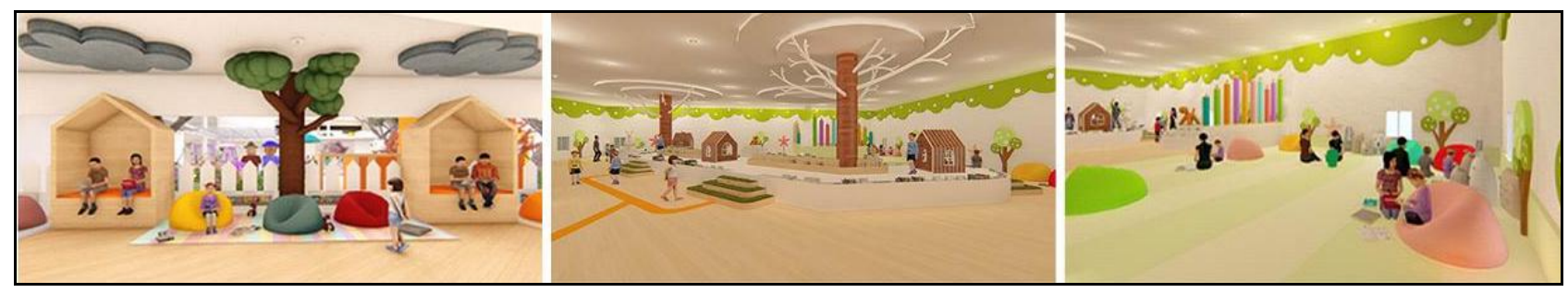

Gambar 18: Interior Bangunan Perpustakaan Anak Kota Pontianak Sumber: Penulis, 2020

\section{Kesimpulan}

Perancangan bangunan Perpustakaan Anak Kota Pontianak direncanakan dengan memperhatikan fungsi perpustakaan dan penggunanya yaitu anak. Oleh karena itu perancangan perpustakaan anak berbeda dengan perpustakaan umum. Perpustakaan anak adalah perpustakaan yang dikhususkan untuk mewadahi kegiatan belajar anak yang disesuaikan untuk memenuhi kebutuhan anak secara khusus. Adapun kegiatan yang ada di perpustakaan anak adalah kegiatan belajar dan bermain secara edukatif serta penyediaan layanan anak sebagai kegiatan pendukung. Proses perancangan perpustakaan anak menghasilkan perpustakaan yang mengekspresikan suasana kondusif, imajinatif dan rekreatif yang sesuai dengan karakteristik anak selaku pengguna utama yang diolah dalam penataan ruang dalam dan luar melalui permainan warna dan bentuk.

\section{Ucapan Terima Kasih}

Ucapan syukur kepada Tuhan Yang Maha Esa atas karunianya. Kepada orang tua dan keluarga penulis atas motivasi dan dukungannya. Kepada para dosen pembimbing Proyek Tugas Akhir yaitu Bapak Yudi Purnomo, ST, MT selaku pembimbing utama dan Bapak Irwin, ST, MT selaku pembimbing pendamping yang telah memberikan kritik dan saran untuk penulis. Kepada seluruh teman-teman yang telah memberikan doa dan dukungan dalam pengerjaan Proyek Tugas Akhir ini, penulis mengucapkan terima kasih sebesar-besarnya. 


\section{Daftar Pustaka}

Central Connecticut State University. (2016, September 19). World's Most Literate Nations. Retrieved from https://www.ccsu.edu/wmln/rank.html

Dinas Kependudukan dan Pencatatan Sipil. (2019, September 24). Data Distribusi Menurut Kelompok Umur Kota Pontianak 2019. Retrieved from https://disdukcapil.pontianakkota.go.id/download/statistik-penduduk-tahun-2018

Dinas Perpustakaan dan Kearsipan Kota Pontianak. (2019, September 6). Grafik Jumlah Pengunjung Beberapa Rumah Baca dan Perpustakaan di Kota Pontianak Tahun 2018 dan 2019. Retrieved from https://web.disperpusib.com/

Dirjen Pendidikan Tinggi RI. (2004). Pedoman Perpustakaan Edisi 3. Jakarta: Dirjen Pendidikan Tinggi RI

Human Development Reports. (2019, September 23). Indikator Pembangunan Manusia. Retrieved from http://hdr.undp.org/en/countries/profiles/IDN.

Kamus Besar Bahasa Indonesia. (2019, September 3). Makna Kata Imajinasi. Retrieved from https://kbbi.web.id/imajinasi

Kamus Besar Bahasa Indonesia. (2019, September 3). Makna Kata Kondusif. Retrieved from https://kbbi.web.id/kondusif

Kamus Besar Bahasa Indonesia. (2019, September 3). Makna Kata Rekreasi. Retrieved from https://kbbi.web.id/rekreasi

Mursid. (2015). Pengembangan Pembelajaran Paud. Bandung: PT Remaja Rosdakarya

Perpustakaan Nasional RI. (2011). Standar Nasional Indonesia Bidang Perpustakaan Dan Kepustakawanan. Jakarta: Perpustakaan Nasional Republik Indonesia

Persia, Aziza Nur. (2013). Peran Perpustakaan Anak di Rumah Sakit Kanker Dharmais Jakarta. Jurnal Ilmu Perpustakaan, 2(3), 5. Retrieved from https://ejournal3.undip.ac.id/index.php/jip/article/view/3489.

Sekretariat Daerah Kota Pontianak. (2013). Peraturan Daerah Kota Pontianak No 2 Tahun 2013 Tentang Rencana Tata Ruang Wilayah Kota Pontianak Tahun 2013-2033. Pontianak: Sekretariat Daerah Kota Pontianak

Solihin, Lukman et al. (2019). Indeks Aktivitas Literasi Membaca 34 Provinsi. Jakarta: Pusat Kebijakan Pendidikan \& Kebudayaan Penelitian \& Pengembangan Kementrian Pendidikan \& Kebudayaan

Sulistyo, Basuki. (1994). Pengantar Ilmu Perpustakaan. Jakarta: PT Gramedia Pustaka Utama

Veramyta, Rohana. (2012). Perpustakaan Anak Sebagai Sarana Pendukung Tumbuh Kembang Anak di Kota Yogyakarta. Yogyakarta: Universitas Atmajaya Yogyakarta 